\title{
Traversing the soft/hard power binary: the case of the Sino-Japanese territorial dispute
}

\author{
Linus Hagström ${ }^{1 *}$ (D) and Chengxin $\operatorname{Pan}^{2}$ (D) \\ ${ }^{1}$ Swedish Defence University and Swedish Institute of International Affairs, Stockholm, Sweden and ${ }^{2}$ Deakin University, \\ Victoria, Australia \\ ${ }^{*}$ Corresponding author. Email: linus.hagstrom@fhs.se
}

(Received 9 January 2019; revised 11 June 2019; accepted 12 July 2019; first published online 27 August 2019)

\begin{abstract}
Soft power and hard power are conceptualised in International Relations as empirically and normatively dichotomous, and practically opposite - one intangible, attractive, and legitimate, the other tangible, coercive, and less legitimate. This article critiques this binary conceptualisation, arguing that it is discursively constructed with and for the construction of Self and Other. It further demonstrates that practices commonly labelled and understood as soft power and hard power are closely interconnected. Best understood as 'representational force' and 'physical force' respectively, soft and hard power intertwine through the operation of productive and disciplinary forms of power. We illustrate this argument by analysing the Sino-Japanese dispute over the Diaoyu/Senkaku Islands. Both governments exercise representational force in constructing their respective versions of events and Self/Other. The soft/hard power binary itself plays a performative role as the Self is typically associated with soft power and the Other with hard power. The operation of productive power, moreover, privileges the attractiveness of the former and the repellence of the latter, and disciplinary power physically enforces these distinctions on subjects in both states. Finally, reinforced Self/Other distinctions legitimise preparations for violence against the Other on both sides, thus exposing how fundamentally entangled soft and hard power are in practice.
\end{abstract}

Keywords: Diaoyu/Senkaku Islands; Disciplinary Power; Productive Power; Sino-Japanese Relations; Soft Power

\section{Introduction}

Commonly defined as 'the ability to get what you want through attraction rather than coercion or payments', 1 soft power has itself become immensely attractive as both a concept and policy practice. ${ }^{2}$ Northeast Asia is a case in point. Soft power has become 'the most often used policy term' in the region, ${ }^{3}$ gaining traction in academic and policy circles in China and Japan alike. ${ }^{4}$

\footnotetext{
${ }^{1}$ Joseph S. Nye Jr, Soft Power: The Means to Success in World Politics (New York: Public Affairs, 2004), p. x.

${ }^{2}$ Todd Hall, 'An unclear attraction: a critical examination of soft power as an analytical category', Chinese Journal of International Politics, 3:2 (2010), pp. 189-211; Johan Eriksson and Ludvig Norman, 'Political utilisation of scholarly ideas: the "clash of civilisations" vs. "soft power" in US foreign policy', Review of International Studies, 37:1 (2011), pp. 417-36.

${ }^{3}$ Koichi Iwabuchi, 'Against banal inter-nationalism', Asian Journal of Social Science, 41:5 (2014), p. 443.

${ }^{4} \mathrm{Li}$ Mingjiang, 'China debates soft power', Chinese Journal of International Politics, 2:2 (2008), pp. 287-308; Akiko Fukushima, 'Modern Japan and the quest for attractive power', in Sook Jong Lee and Jan Melissen (eds), Public Diplomacy and Soft Power in East Asia (Houndmills, Basingstoke, Hampshire and New York: Palgrave Macmillan, 2011), pp. 65-90; Jing Sun, Japan and China as Charm Rivals: Soft Power in Regional Diplomacy (Ann Arbor, MI: University of Michigan Press, 2012).

(C) British International Studies Association 2019. This is an Open Access article, distributed under the terms of the Creative Commons Attribution-NonCommercial-NoDerivatives licence (http://creativecommons.org/licenses/by-nc-nd/4.0/), which permits non-commercial re-use, distribution, and reproduction in any medium, provided the original work is unaltered and is properly cited. The written permission of Cambridge University Press must be obtained for commercial re-use or in order to create a derivative work.
} 
Nonetheless, tensions abound not least in Sino-Japanese relations - over disputed territory, history, and colliding quests for regional leadership. To enhance their security in the light of how they interpret various developments, both China and Japan are currently beefing up their military preparedness, often referred to as hard power, and the risk of a security dilemma appears real. ${ }^{5}$ The prevalence of hard power sits uncomfortably with the growing attractiveness of soft power.

How can we account for this apparently uneasy juxtaposition of soft power and hard power in Northeast Asian international politics? For some, it simply reflects a gap between the harsh reality of hard power politics on the ground and a certain soft power-loving idealism found in academia and policy circles. ${ }^{6}$ For others, the continuation of hard power politics and its dangerous consequences should invite the intervention of soft power. ${ }^{7}$ While they hold different views on soft power, as either a naive or a normatively superior alternative to hard power, both arguments share the dominant view in International Relations (IR) scholarship that soft and hard power are empirically antithetical categories.

By contrast, the present article aims to reconsider this interpretation of soft and hard power and propose two interrelated ways of accounting for their co-presence, for example in Northeast Asian international politics. First, we deconstruct the soft/hard power binary. Instead of referring to two empirically distinctive categories of power, we argue that soft and hard power function performatively. Moreover, they are discursively co-constituted so that one cannot exist without the other. This co-constitution moreover occurs in conjunction with, and in the service of, Self/Other construction. Second, we demonstrate that practices commonly labelled and understood as soft power also have unexpectedly close connections with practices labelled and understood as hard power. Based on the work by Janice Bially Mattern and others, we call the former 'representational force $^{8}$ - in essence, the capacity to get audiences to empathise and identity with the Self (and against the Other). However, contra this previous work we argue that representational force ('soft power') legitimises and enables the use of physical force ('hard power'), regardless of whether the former is explicitly labelled and understood as soft power.

The second step heeds Michael Barnett and Raymond Duvall's call to 'work with multiple conceptions of power' ${ }^{99}$ to establish their relationship more precisely, ${ }^{10}$ but is not intended to result in a comprehensive conceptualisation of power in IR akin to the two scholars' own taxonomy. Instead, the article makes two distinct contributions to our understanding of the soft power phenomenon. First, we theorise how productive power - a Foucauldian notion that Barnett and Duvall helped popularise in IR - intervenes and makes it possible for actors to exercise representational force and for audiences to be persuaded. Second, disciplinary power is another notion drawn from Michel Foucault's work and we use it to theorise how identity construction - whether in the form of representational force or productive power involves physically disciplining the subjects of power, for example by punishing those who do not voice unequivocal allegiance to the Self.

\footnotetext{
${ }^{5}$ Adam P. Liff and G. John Ikenberry, 'Racing toward tragedy? China's rise, military competition in the Asia Pacific, and the security dilemma', International Security, 39:2 (2014), pp. 52-91.

${ }^{6}$ Robert Kagan, Of Paradise and Power: America and Europe in the New World Order (New York: Vintage Books, 2004); John Mearsheimer, 'E. H. Carr vs. Idealism: the battle rages on', International Relations, 19:2 (2005), pp. 139-52; Ernest J. Wilson III, 'Hard power, soft power, smart power', Annals of the American Academy of Political and Social Science, 616 (2008), pp. 110-24; Christopher Layne, 'The unbearable lightness of soft power', in Inderjeet Parmar and Michael Cox (eds), Soft Power and US Foreign Policy: Theoretical, Historical and Contemporary Perspectives (London and New York: Routledge, 2010), pp. 51-82.

${ }^{7}$ Ankit Panda, 'Soft power and China-Japan relations', The Diplomat (18 December 2013), available at: \{https://thediplomat.com/2013/12/soft-power-and-china-japan-relations/\}. Unless otherwise noted, all Internet sources quoted in this article were accessed on 7 December 2018.

${ }^{8}$ Janice Bially Mattern, 'Why "soft power” isn't so soft: Representational force and the sociolinguistic construction of attraction in world politics', Millennium, 33:3 (2005), pp. 582-612.

${ }^{9}$ Michael Barnett and Raymond Duvall, 'Power in international politics', International Organization, 59:1 (2005), p. 40.

${ }^{10}$ Ibid., p. 67.
} 
The first critique outlined above is crucial for undertaking the second one, since soft power and hard power are among the identity signifiers that actors use to get audiences to empathise and identify with the Self and against the Other - that is, along with binaries such as democratic/undemocratic and peaceful/unpeaceful. The fact that the self-identified 'soft' Self applies disciplinary power and physical force towards its Others understood as 'hard' goes some way towards explaining the apparently uneasy juxtaposition of soft power and hard power in Northeast Asian international politics.

Some may find the sparring with soft power undertaken in this article to be redundant. After all, liberal and realist IR theorists have dismissed the term as a 'a huge conceptual misstep' ${ }^{11}$ and 'a theoretical construct' that is not robust' and 'does not offer any independent contribution to understanding ... international politics' ${ }^{12}$ Yet, for all its perceived conceptual shortcomings, soft power plays a major role in political commentary, policy practice, as well as in IR scholarship. The continued use and reproduction of the term, and its widely perceived binary relationship with hard power, mean that the concept constitutes an important phenomenon that can hardly be disregarded simply because of its limited analytical purchase.

Section two examines the growing body of literature that has begun to refine or question the conventional binary view of soft power and hard power. While correctly challenging the rigidity of the binary, previous works tend to reify soft and hard power as empirically separate - if not always sharply bounded - categories. In section three, we undertake the first critique by reviewing how the binary treatment of soft and hard power in the literatures on China and Japan plays a performative role, and by showing how the meaningful existence of one form of power always depends on the discursive construction of the other. In section four, we lay the theoretical groundwork for the second critique, by developing a theoretical heuristic that helps to illuminate how representational force and physical force intertwine in practice. Drawing on the concepts of productive and disciplinary power, we again conjecture that certain identity constructions are privileged over others and physically enforced on the subjects of power. These forms of power, moreover, intersect in a way that can legitimise and enable the use of physical force, or what is commonly labelled and understood as hard power. Section five applies the latter theoretical argument to the case of the Sino-Japanese dispute over the Senkaku/Diaoyu Islands in the East China Sea. We do not seek to explain what caused the dispute, or to validate the theoretical heuristic through empirical testing. Instead, we aim to demonstrate its 'analytical generality'13 or applicability - even to instances of international politics that are not labelled and understood as soft power but conform to the definition of representational force.

\section{Traversing the soft/hard power binary: Existing perspectives}

As we attempt to traverse the soft/hard power binary, we join a growing body of literature that consists of three broad perspectives. First, a contextual argument holds that what counts as soft and hard power is not clear-cut but depends on the practical context in which resources are deployed. ${ }^{14}$ For instance, while often understood as hard power, the possession and use of military and economic resources may at times generate attraction and soft power. ${ }^{15}$ A second,

\footnotetext{
${ }^{11}$ David Baldwin, 'Power and international relations', in Walter Carlsnaes, Thomas Risse-Kappen, and Beth A. Simmons (eds), Handbook of International Relations (London: Sage, 2002), p. 186.

${ }^{12}$ Layne, 'The unbearable lightness of soft power'.

${ }^{13}$ Vincent Pouliot, 'Practice tracing', in Andrew Bennett and Jeffrey T. Checkel (eds), Process Tracing: From Metaphor to Analytical Tool (Cambridge: Cambridge University Press), pp. 238-9.

${ }^{14}$ James Traub, 'The new hard soft power', New York Times Magazine (20 January 2005), available at: \{https://www. nytimes.com/2005/01/30/magazine/the-new-hardsoft-power.html\}.

${ }^{15}$ Thomas U. Berger, 'Japan in Asia: a hard case for soft power', Orbis, 54:4 (2010), pp. 565-82; Giulio M. Gallarotti, 'Soft power: What it is, why it's important, and the conditions for its effective use', Journal of Political Power, 4:1 (2011), pp. 25-47; David W. Kearn, 'The hard truths about soft power', Journal of Political Power, 4:1 (2011), pp. 65-85; Jean-Marc F. Blanchard
} 
closely related, perspective is a spectral conception of power, according to which soft and hard power are continuous rather than dichotomous. ${ }^{16}$ András Simonyi and Judit Trunkos, for example, argue that there is a linear and progressive softening from hard to soft. ${ }^{17}$ Elsewhere, Marcos Kounalakis and Simonyi propose a spectral power framework for understanding the 'contemporary complexities of the soft/hard power mix'. ${ }^{18}$

Contextual and spectral perspectives are critical of the fact that the soft/hard power dichotomy 'masks the potential for using hard power resources to implement soft power and vice versa'. ${ }^{19}$ Hence, they take what Jef Huysmans calls 'definition' or 'conceptual analysis' approaches to soft and hard power as concepts, ${ }^{20}$ and try to define their meanings in a way that better reflects empirical reality. They are also interested in how to utilise and combine various resources and forms of power flexibly to achieve optimal outcomes, for example, by way of 'smart power'. ${ }^{21}$ This approach is not necessarily in disagreement with Joseph Nye - the scholar who coined the term soft power. He admits that 'The distinction between [soft and hard power] is one of degree' and states that the two forms of power exist 'along a spectrum from coercion to economic inducement to agenda setting to pure attraction'. ${ }^{22}$ Although these two perspectives allow for some more graduated and less rigid ways of differentiating between soft and hard power, their challenge to the binary is largely on empirical grounds.

A third, more radical, challenge is levelled by constructivist scholars who argue that the exercise of soft power can be so coercive that it is difficult to distinguish from hard power. ${ }^{23}$ Bially Mattern, in particular, argues that attraction does not occur naturally but through the use of representational force. This is a sociolinguistic process, whereby a speaker forces an audience to empathise and identify with his or her narrative representation of reality. If the audience neglects to do so, its ontological security - or 'sense of continuity and order in events' regarding selfidentity $^{24}$ - is threatened. A case in point quoted by Bially Mattern is when US President George W. Bush attracted, or perhaps rather coerced, domestic and international audiences to empathise and identify with the US post-9/11 by declaring that 'you are either with us or with the terrorists' ${ }^{25}$ Bush may not have labelled or even understood his own utterance as an instance of soft power, but Bially Mattern's point is that representational force epitomises soft power, regardless of an actor's intentionality.

This radical perspective helps to shed light on how discreet speakers rhetorically coerce audiences into accepting dominant Self/Other constructions. Since we take this to be the most useful critique of soft power to date, we choose here to replace the term soft power with representational force. Yet, while correctly disputing the attraction/coercion binary at the core of Nye's

and Fujia Lu, 'Thinking hard about soft power: a review and critique of the literature on China and soft power', Asian Perspective, 36:4 (2012), pp. 565-89.

${ }^{16}$ Steven B. Rothman, 'Revising the soft power concept: What are the means and mechanisms of soft power?', Journal of Political Power, 4:1 (2011), pp. 49-64.

${ }^{17}$ András Simonyi and Judit Trunkos, 'Eliminating the soft/hard power dichotomy', in Aude Jehan and András Simonyi (eds), Smarter Power: The Key to a Strategic Transatlantic Partnership (Washington, DC: Center for Transatlantic Relations, 2014), p. 16.

${ }^{18}$ Marcos Kounalakis and András Simonyi, The Hard Truth About Soft Power (Los Angeles, CA: Figueroa Press 2011 ), p. 6.

${ }^{19}$ Rothman, 'Revising the soft power concept', p. 50.

${ }^{20}$ Jef Huysmans, 'Security! What do you mean? From concept to thick signifier', European Journal of International Relations, 4:2 (1998), pp. 226-55.

${ }^{21}$ Wilson, 'Hard power, soft power, smart power'.

${ }^{22}$ Nye, Soft Power, p. 7.

${ }^{23}$ Bially Mattern, 'Why “soft power” isn't so soft'; Geraldo Zahran and Leonardo Ramos, 'From hegemony to soft power: Implications of a conceptual change', in Parmar and Cox (eds), Soft Power and US Foreign Policy, pp. 12-31; Astrid Nordin, 'How soft is "soft power"? Unstable dichotomies at Expo 2010', Asian Perspective, 36:4 (2012), pp. 591-613.

${ }^{24}$ Anthony Giddens, Modernity and Self-Identity: Self and Society in the Late Modern Age (Stanford, CA: Stanford University Press, 1991), p. 243.

${ }^{25}$ Bially Mattern, 'Why “soft power” isn't so soft', p. 606. 
conceptualisation, ${ }^{26}$ Bially Mattern subscribes to a dual ontology of power that is ultimately similar to Nye's. ${ }^{27}$ Despite her stronger commitment to the notion that soft power relies on social construction, she does not recognise that the conceptual binary is itself socially and discursively constructed and plays a performative role in the construction of Self/Other. Thus, she ends up conceding that soft power, 'however unappealing, is normatively more appealing than the power politics of war, empire and physical conquest'. ${ }^{28}$

\section{Critique One: Deconstructing the soft/hard power binary}

Despite attempts to loosen the soft/hard power binary in the existing research discussed above, the two forms of power continue to be reified as ontologically separate. In the words of Nye, 'soft power does not depend on hard power'. ${ }^{29}$ The former is typically construed as more intangible, attractive, and legitimate, the latter as more tangible, coercive, and illegitimate. Yet, just as the gender binary is 'socially instituted to function as irreducible', ${ }^{30}$ we argue that soft/hard power distinctiveness is also the effect of dichotomous construction in discourse.

If we accept the poststructuralist premise that 'language constitutes, produces, and reproduces its own system of referents', ${ }^{31}$ then soft and hard power also cannot exist outside of the discourse that gives them meaning. Thus, instead of seeing soft and hard power as two concepts that correspond to empirical reality, they may be conceptualised as what Huysmans calls 'thick signifiers. ${ }^{32}$ Since they acquire meaning by being differentiated from other signifiers (not least each other), soft and hard power are self-referential and performative rather than descriptive. ${ }^{33}$ In other words, the ontology of soft and hard power (and indeed of power as a social fact) is fundamentally discursive. The fact that soft and hard power appear to be separate categories is exactly the performative function of discursive construction, or more precisely the juxtaposition of differential signs. ${ }^{34}$ Since discourse constructs the objects of which it speaks as real and a matter of common sense, ${ }^{35}$ their discursive ontology tends to be obscured. Deconstructive methods help render it more visible.

Deconstruction is a method of critique designed to problematise 'the hierarchical oppositions that have structured Western thought: inside/outside, mind/body, literal/metaphorical, speech/ writing, presence/absence, nature/culture, form/meaning. ${ }^{36}$ As systems of signification, discourses tend to be structured through such binary oppositions. ${ }^{37}$ According to Jonathan Culler, 'To deconstruct an opposition is to show that it is not natural and inevitable but a construction, produced by discourses that rely on it. ${ }^{38}$ From such a perspective, there is nothing

\footnotetext{
${ }^{26}$ Ibid., pp. 583, 586-7; for example, Nye, Soft Power, p. x.

${ }^{27}$ Bially Mattern, 'Why "soft power" isn't so soft', p. 591.

${ }^{28}$ Ibid., pp. 611-12.

${ }^{29}$ Nye, Soft Power, pp. 5, 9.

${ }^{30}$ Gill Jagger, Judith Butler: Sexual Politics, Social Change and the Power of the Performative (London: Routledge, 2008), p. 6.

${ }^{31}$ Bradley Klein, 'The textual strategies of the military: or, have you read any good defence manuals lately?', in James Der Derian and Michael J. Shapiro (eds), International/Intertextual Relations: Postmodern Readings of World Politics (New York: Lexington Books, 1989), p. 100.

${ }^{32}$ Huysmans, 'Security!'.

${ }^{33}$ Ibid., pp. 228, 232.

${ }^{34}$ Lene Hansen, Security as Practice: Discourse Analysis and the Bosnian War (London: Routledge, 2006), pp. 18-19.

${ }^{35}$ Chengxin Pan and Oliver Turner, 'Neoconservatism as discourse: Virtue, power and US foreign policy', European Journal of International Relations, 23:1 (2017), p. 79.

${ }^{36}$ Jonathan Culler, Literary Theory: A Very Short Introduction (Oxford: Oxford University Press, 1997), p. 127.

${ }^{37}$ Jennifer Milliken, 'The study of discourse in international relations: a critique of research and methods', European Journal of International Relations, 5:2 (1999), pp. 225-54.

${ }^{38}$ Culler, Literary Theory, p. 127.
} 
inherently soft or hard about the possession or use of seemingly self-evident soft and hard power resources.

The "performative character of "power"" 39 moreover means that its articulation is intimately linked to the construction of Self/Other, and vice versa. For instance, discourses of power in IR - whether they revolve around 'soft power', 'status quo power', 'revisionist power', or 'normative power Europe' - are never far removed from their explicit or implicit reference to certain subjects of power. ${ }^{40}$ In many instances, soft and hard power are also virtually meaningless without their associated identities. ${ }^{41}$ Just as the construction of the Self entails the construction of the Other and vice versa, ${ }^{42}$ soft power, which tends to be linked with the construction of the Self, depends on the simultaneous construction of hard power and its associated Other. Consequently, soft and hard power are discursively co-constituted. The fact that the concepts emerged together testifies to their interdependence and performative inseparability.

Deconstructive and performative approaches to IR have produced a sizeable body of literature, particularly on the concept of security. ${ }^{43}$ Some scholars have begun to apply these insights to the analysis of power, posing important questions about what 'power' does when invoked. ${ }^{44}$ According to Craig Hayden, for instance, soft power as a term 'is not fixed, but a malleable signifier of political action'. ${ }^{45}$ Erik Ringmar, moreover, notes that from a performative perspective there is little difference between soft and hard power, because to be powerful, whether in terms of one form of power or the other, is 'less important than to appear to be powerful'. ${ }^{46}$ These insightful though brief interventions notwithstanding, to date the soft/hard power binary has not been systematically scrutinised from this perspective. ${ }^{47}$

The existing literature on Northeast Asian international politics with a focus on Chinese and Japanese soft power illustrates how the soft/hard power binary is discursively constructed and plays a performative role in the construction of Self/Other. To begin with, some Chinese scholars repudiate widespread apprehension about China's agglomeration of economic and military capabilities, or hard power, ${ }^{48}$ and try to 'reduce alarm ${ }^{49}$ by stressing the benign nature of China's

\footnotetext{
${ }^{39}$ Stefano Guzzini, Power, Realism and Constructivism (New York: Routledge, 2013), p. 229, fn. 18.

${ }^{40}$ For example, throughout Nye's analysis of soft power, one obvious subject is the United States and its success in world politics. See, for example, Oliver Turner and Nicola Nymalm, 'Morality and progress: IR narratives on international revisionism and the status quo', Cambridge Review of International Affairs, Online First (21 June 2019), available at: \{https://doi.org/ 10.1080/09557571.2019.1623173\}.

${ }^{41}$ Some studies of soft power have made the (not necessarily ontological) connection between soft power and identity, but hard power is yet to be understood through the same discursive process of identity construction. Craig Hayden, The Rhetoric of Soft Power: Public Diplomacy in Global Contexts (Lanham, MD: Lexington Books, 2012); Ty Solomon, 'The affective underpinnings of soft power', European Journal of International Relations, 20:3 (2014); Valentina Feklyunina, 'Soft power and identity: Russia, Ukraine and the "Russian world(s)", European Journal of International Relations, 22:4 (2016), pp. 773-96.

${ }^{42}$ Stuart Hall, 'Introduction: Who needs “identity"?', in Stuart Hall and Paul du Gay (eds), Questions of Cultural Identity (London: SAGE, 1996), pp. 4-5; Chengxin Pan, Knowledge, Desire and Power in Global Politics: Western Representations of China's Rise (Cheltenham: Edward Elgar, 2012).

${ }^{43}$ Huysmans, 'Security!'; Hansen, Security as Practice; see also Guzzini, Power, Realism and Constructivism, pp. 229-30.

${ }^{44}$ Guzzini, Power, Realism and Constructivism, pp. 229-30.

${ }^{45}$ Hayden, The Rhetoric of Soft Power, p. 5.

${ }^{46}$ Erik Ringmar, 'Performing international systems: Two East-Asian alternatives to the Westphalian order', International Organization, 66:1 (2012), p. 19.

${ }^{47}$ Winkler understands the reification of soft power as driven by concept coalitions and their use of narratives. See Stephanie Christine Winkler, "Soft power is such a benign animal": Narrative power and the reification of concepts in Japan', Cambridge Review of International Affairs, Online First (19 June 2019), available at: \{https://doi.org/10.1080/ 09557571.2019.1623171\}.

${ }^{48}$ See, for example, Aaron L. Friedberg, 'The sources of Chinese conduct: Explaining Beijing's assertiveness', Washington Quarterly, 37:4 (2014), pp. 133-50; Markus B. Liegl, China's Use of Military Force in Foreign Affairs: The Dragon Strikes (London: Routledge, 2017).

${ }^{49}$ Jacques deLisle, 'Soft power in a hard place: China, Taiwan, cross-strait relations and US policy', Orbis, 54:4 (2010), p. 493.
} 
rise, as epitomised by its alleged peacefulness and soft power. ${ }^{50}$ According to Sheng Ding: 'when a rising power [read China] tries to develop its soft power resources and wield its soft power, its revisionist policy orientation will greatly decrease'. ${ }^{51}$

Debates about China's soft power typically understand the phenomenon as a function of China's establishment of Confucius Institutes, ${ }^{52}$ the popularity of Chinese culture, language education, medicine and religion, and the expansion of Chinese media outlets, as well as China's hosting of major international events, as if the existence and spread of such assets and means themselves epitomised the exercise of soft power. ${ }^{53}$ Yet, some maintain that unless China embraces democratic norms, which Nye takes to be central to the exercise of soft power, ${ }^{54}$ it will inevitably continue to be regarded as a revisionist hard power rather than a peaceful soft power. ${ }^{55}$ Indeed, China's attempts to attract foreign audiences are increasingly construed as threatening propaganda, ${ }^{56}$ or 'sharp power', ${ }^{57}$ rather than soft power.

The literature on Japan's soft power is similar to that on China in that it typically takes soft power to derive directly from resources understood as soft, primarily the worldwide circulation and appeal of Japanese comics and animated films, but also architecture, budo, cuisine, design, art, games, language, and music. ${ }^{58}$ Comparing Japanese and Chinese soft power strategies, Yee-Kuang Heng concludes that 'Japan is currently the "softer" power. ${ }^{\text {59 }}$ Some Japanese and

\footnotetext{
${ }^{50}$ Yiwei Wang, 'Public diplomacy and the rise of Chinese soft power', Annals of the American Academy, 616 (2008), pp. 257-73; Xin Li and Verner Worm, 'Building China's soft power for peaceful rise', Journal of Chinese Political Science, 16:69 (2011), pp. 69-89; Wanfa Zhang, 'Has Beijing started to bare its teeth? China's tapping of soft power revisited', Asian Perspective, 36:4 (2012), pp. 615-39.

${ }^{51}$ Sheng Ding, 'Analyzing rising power from the perspective of soft power: a new look at China's rise to the status quo power', Journal of Contemporary China, 19:64 (2010), p. 255.

${ }^{52}$ James F. Paradise, 'China and international harmony: the role of Confucius Institutes in bolstering Beijing's soft power', Asian Survey, 49:4 (2009), pp. 647-69; Anja Lahtinen, 'China's soft power: Challenges of Confucianism and Confucius Institutes', Journal of Comparative Asian Development, 14:2 (2015), pp. 200-26; Ying Zhou and Sabrina Luk, 'Establishing Confucius Institutes: a tool for promoting China's soft power', Journal of Contemporary China, 25:100 (2016), pp. 628-42.

${ }^{53}$ Bates Gill and Yanzhong Huang, 'Sources and limits of Chinese "soft power", Survival, 48:2 (2006), pp. 17-36; Yanzhong Huang and Sheng Ding, 'Dragon's underbelly: an analysis of China's soft power', East Asia, 23:4 (2006), pp. 22-44; Wang, 'Public diplomacy and the rise of Chinese soft power'; Joseph S. Nye Jr and Jisi Wang, 'Hard decisions on soft power: Opportunities and difficulties for Chinese soft power', Harvard International Review, 31:2 (2009), pp. 1822; Blanchard and Lu, 'Thinking hard about soft power'; David Shambaugh, 'China's soft-power push: the search for respect', Foreign Affairs, 94:4 (2015), pp. 99-107. For a recent critique of this resource-based approach to Chinese soft power, see Chengxin Pan, Benjamin Isakhan, and Zim Nwokora, 'Othering as soft-power discursive practice: China Daily's construction of Trump's America in the 2016 presidential election', Politics, Online First (17 April 2019), available at: \{https://doi.org/10. $1177 / 0263395719843219\}$.

${ }^{54}$ Nye, Soft Power, p. x.

${ }^{55}$ Nye, Soft Power; Huang and Ding, 'Dragon's underbelly'; Ingrid d'Hooghe, 'Into high gear: China's public diplomacy', The Hague Journal of Diplomacy, 3:1 (2008), pp. 37-61; Nye and Wang, 'Hard decisions on soft power'.

${ }^{56}$ deLisle, 'Soft power in a hard place'; Zhou and Luk, 'Establishing Confucius Institutes'.

${ }^{57}$ Christopher Walker and Jessica Ludwig, 'The meaning of sharp power: How authoritarian states project influence', Foreign Affairs (16 November 2017), available at: \{https://www.foreignaffairs.com/articles/china/2017-11-16/meaningsharp-power\}; Joseph S. Nye Jr, 'How sharp power threatens soft power: the right and wrong ways to respond to authoritarian influence', Foreign Affairs (24 January 2018), available at: \{https://www.foreignaffairs.com/articles/china/2018-01-24/howsharp-power-threatens-soft-power\}.

${ }^{58}$ Peng Er Lam, 'Japan's quest for “soft power”: Attraction and limitation', East Asia, 24:4 (2007), pp. 349-63; Yoshiko Nakano, 'Shared memories: Japanese pop culture in China', in Yasushi Watanabe and David L. McConnell (eds), Soft Power Superpowers: Cultural and National Assets of Japan and the United States (Armonk, NY: M. E. Sharpe 2008), pp. 111-27; Nissim Kadosh Otmazgin, 'Contesting soft power: Japanese popular culture in East and Southeast Asia', International Relations of the Asia-Pacific, 8:1 (2008), pp. 73-101; Nakamura Ichiya, 'Kūru Japan o gaikō, sangyō seisaku ni ika ni ikasu ka [How to make best use of cool Japan in diplomacy and industrial policy]', Gaikō [Foreign Policy], 3 (2010), pp. 42-7.

${ }^{59}$ Yee-Kuang Heng, 'Mirror, mirror on the wall, who is the softest of them all? Evaluating Japanese and Chinese strategies in the "soft" power competition era', International Relations of the Asia-Pacific, 10:2 (2010), p. 300.
} 
foreign analysts propose that Japan should further augment its soft power by more clearly differentiating itself from China, emphasising Japan's democracy, human rights, equality, liberty and, above all, peaceful trajectory since the end of the Second World War. ${ }^{60}$ This indeed seems to have been part of Japan's strategy in recent years. ${ }^{61}$

At the same time, Chinese scholars refute the notion that there is anything soft about Japan's policies, past or present. They portray Japan and its ally, the United States, as the champions of hard power, with military force at their core. ${ }^{62}$ Wanfa Zhang, for example, juxtaposes China's soft power with Japan's baring of 'its teeth'. ${ }^{63}$ Yan Xuetong claims that soft power depends on political and moral power. Since Japan remains an immoral country for denying its crimes during the colonial era, it does not enjoy soft power. ${ }^{64}$ Meanwhile, non-Chinese works agree that Japan's wartime conduct may negate the attraction of Japanese cultural artefacts in Northeast Asia. ${ }^{65}$

This brief section demonstrates how the existing literatures on Chinese and Japanese soft power construct the soft/hard power binary together with and in the service of Self/Other construction. Soft power is the discursively produced ideal and it is more typically associated with the Self, whereas hard power is seen to characterise the Other. Indeed, scholarly works are complicit in this hierarchical differentiation.

\section{Critique Two: Pinpointing the operation of productive and disciplinary power}

The previous section goes some way to explaining the co-presence of soft power and hard power in Northeast Asian international politics: it is difficult to think or talk about one without juxtaposing it with the other. Moreover, if the Self is associated with soft power, it can make sense to protect it from the hard power of the Other, by using physical force if necessary. ${ }^{66}$ To avoid reifying the soft/hard power binary any further, we propose that the best way forward may be to use other terms when analysing phenomena that are usually labelled and understood as soft and hard power. It is true that it is hardly possible to abandon all terms that currently come in binaries and participate in the construction of identities, because that would entail giving up democracy/dictatorship, peace/war, security/insecurity, and many other concepts that have similar discursive functions. Yet, there may be less dichotomous ways of representing the practices commonly labelled and understood as soft and hard power.

\footnotetext{
${ }^{60}$ Nakamura, 'Kūru Japan o gaikō, sangyō seisaku ni ika ni ikusu ka'; Ogoura Kazuo, 'Nihon no “jiko kitei” to gyakuten no hassō [Japan's identity and reverse ideas]', Gaikō [Foreign Policy], 3 (2010), pp. 54-61; Watanabe Hirotaka, 'Nihon gaikō no mirai o ninau bunka gaikō [The cultural diplomacy that carries the future of Japanese diplomacy]', Gaikō [Foreign Policy], 3 (2010), pp. 62-74; Hanscom Smith, 'Toward a universal Japan: Taking a harder look at Japanese soft power', Asia Policy, 15 (2013), pp. 115-26.

${ }^{61}$ Alexander Bukh, 'Revisiting Japan's cultural diplomacy: a critique of the agent-level approach to Japan's soft power', Asian Perspective, 38:3 (2014), pp. 461-85.

${ }^{62}$ Feng Zhaokui, "Zhong-Ri guanxi de "jin” yu "tui” - jiyu "qufen kailai” yuanze yuce de keneng qianjing ["Progress" and "regress" of Sino-Japanese relations: Predicted prospects based on the "differentiation" principle]', Riben Xuekan [Japanese Studies], 1 (2017), pp. 1-27; Zhu Haiyan, 'Riben Anbao zhengce de xin fazhan ji yingxiang [Japan's security policy: New development and implications]', Guojiwenti yanjiu [International Studies], 1 (2018), pp. 90-104.

${ }^{63}$ Wanfa Zhang, 'Has Beijing started to bare its teeth? China's tapping of soft power revisited', Asian Perspective, 36:4 (2012), pp. 615-39.

${ }^{64}$ Yan Xuetong, 'Cong hexie shijie kan Zhongguo ruanshili [China's soft power from the perspective of harmonious world]', Huanqiu shibao [Global Times] (19 December 2005), available at: \{http://www.china.com.cn/news/txt/2005-12/19/ content_6065149.htm\}.

${ }^{65}$ Nye, Soft Power; Lam, 'Japan's quest for “soft power”'; Nakano, 'Shared memories'; Otmazgin, 'Contesting soft power'; Berger, 'Japan in Asia'.

${ }^{66}$ Linus Hagström and Astrid H. M. Nordin, 'China's "politics of harmony" and the quest for soft power in international politics', International Studies Review, Online First (9 May 2019), available at: $\{$ https://doi.org/10.1093/isr/viz023\}.
} 
While most soft power analysis to date, including works by Nye himself, ${ }^{67}$ has rehearsed realism's materialist concept of power, ${ }^{68}$ focusing on 'soft' resources, other work (again sometimes including Nye) follows a more relational conceptualisation of power. ${ }^{69}$ The latter is arguably more consistent with Nye's manifold definitions of the term, not least that soft power is the capacity to 'win over the hearts and minds' of others. ${ }^{70}$ This understanding has sparked the most scholarly debate in IR, and soft power is broadly understood as the capacity to affect others by disseminating cultural ideas and narratives. ${ }^{71}$ As seen above, Bially Mattern takes this insight one step further by arguing that the soft power of disseminating narratives actually 'isn't so soft', but can be verbally coercive by threatening the audience's ontological security. ${ }^{72}$

In the context of soft power discussions, moreover, William A. Callahan has argued that narratives about the Self cannot become attractive without including a repellent Other. Hence, the Self becomes attractive - whether as 'peaceful', 'democratic', 'developed', 'harmonious', or indeed a 'soft power' - only if differentiated from an Other cast as 'threatening', 'authoritarian', 'backward', 'disharmonious', 'a hard power', and so on. ${ }^{73}$ Based on these insights, practices commonly labelled and understood as soft power might be characterised as the capacity to get others to empathise and identify with the attractive Self and against the unattractive Other. In our attempt to use less binary terminology, we follow Bially Mattern and call this phenomenon 'representational force' rather than soft power.

The existing literature that understands soft power through a narrative perspective does not just reproduce the soft/hard power binary. It also tends to theorise soft power as strategic social construction and actors as more or less able to construct narratives at will. In contrast, we understand actors as operating within an existing narrative and discursive context, which fundamentally enables and constrains their identity narratives and courses of action more broadly. ${ }^{74}$ In other words, when actors construct narratives about Self and Other, they are enabled and constrained by what Foucault called the productive power of discourse. Foucault writes: 'power produces; it produces reality; it produces domains of objects and rituals of truth. The individual and the knowledge that may be gained of him belong to this production. ${ }^{75}$ Consequently, actors formulate narratives, and exercise representational force, within parameters that are ordered and patterned by the productive power of discourse. ${ }^{76}$ This helps explain why scholars, analysts, and

\footnotetext{
${ }^{67}$ Nye, Soft Power, chs 2, 3 .

${ }^{68}$ On this concept of power, see Brian Schmidt, 'Competing realist conceptions of power', Millennium, 33:3 (2005), pp. 523-49.

${ }^{69}$ Joseph S. Nye Jr, 'Notes for a soft power research agenda', in Felix Berenskoetter and M. J. Williams (eds), Power in World Politics (London and New York: Routledge, 2007), pp. 162-72.

${ }^{70}$ Joseph S. Nye, The Future of Power (New York: Public Affairs, 2011), p. 20.

${ }^{71}$ Matthew Kroenig, Melissa McAdam, and Steven Weber, 'Taking soft power seriously', Comparative Strategy, 29:5 (2010), pp. 412-31; Laura Roselle, Alister Miskimmon, and Ben O’Loughlin, 'Strategic narrative: a new means to understand soft power', Media, War \& Conflict, 7:1 (2014), pp. 70-84; see, for example, d'Hooghe, 'Into high gear'; Heng, 'Mirror, mirror on the wall, who is the softest of them all?'; Ogoura, 'Nihon no "jiko kitei” to gyakuten no hassō'; Watanabe, 'Nihon gaikō no mirai o ninau bunka gaikō'; Li and Worm, 'Building China's soft power for peaceful rise'; Sun, Japan and China as Charm Rivals; Yee-Kuang Heng, 'Beyond “kawaii” pop culture: Japan's normative soft power as global trouble-shooter', The Pacific Review, 27:2 (2014), pp. 169-92; Lahtinen, 'China’s soft power'.

${ }^{72}$ Bially Mattern, 'Why "soft power" isn't so soft'.

${ }^{73}$ William A. Callahan, 'Identity and security in China: the negative soft power of the China dream', Politics, 35:3-4 (2015), pp. 216-29; see also Linus Hagström, 'The Sino-Japanese battle for soft power: Pitfalls and promises', Global Affairs, 1:2 (2015), pp. 129-37; Pan, Isakhan, and Nwokora, 'Othering as soft-power discursive practice'.

${ }^{74}$ Margaret Somers, 'The narrative construction of identity: a relational and network approach', Theory and Society, 23:5 (1994), pp. 605-49; Laura J. Shepherd, 'Ideas/matter: Conceptualising foreign policy practice', Critical Studies on Security, 3:3 (2015), pp. 334-7.

${ }^{75}$ Michel Foucault, Discipline and Punish: The Birth of the Prison (London and New York: Penguin, 1977), p. 194.

${ }^{76}$ Two previous works have made related points: Yong Wook Lee, 'Soft power as productive power', in Sook and Melissen (eds), Public Diplomacy and Soft Power in East Asia, pp. 33-50; Bukh, 'Revisiting Japan's cultural diplomacy'. However, Bukh does not discuss productive power. Lee, 'Soft power as productive power', p. 41 argues that the exercise of soft power is
} 
policymakers in both China and Japan identity the Self as a soft power while casting the Other as the epitome of hard power.

According to Foucault, moreover, productive power intersects with disciplinary power. The latter involves the 'coercive assignment' of binaries normalised through the former. ${ }^{77}$ It operates 'on the very bodies of individuals'; ${ }^{78}$ and the 'technology of representation' is deeply entangled in the subjugation of the body. ${ }^{79}$ As such, disciplinary power helps maintain the discursively produced boundary between Self and Other. Those who cross the boundary by choosing the 'wrong' side are not only met with an ontological threat but may also face physical sanctions, or the threat of such sanctions.

In this sense, we need to rethink Bially Mattern's observation that 'the coercive threat entailed by the logic of "with or against us" was not a physical threat. ${ }^{80}$ In fact, President Bush's statement cited above did involve a threat of physical or bodily sanctions, in addition to the ontological straitjacket implied by the statement. In the face of such a threat, those who do not clearly identify with the civilised and peaceful Self and disavow the barbaric and terrorist Other risk being lumped together with and subjected to similar forms of physical sanctions as the Other. For instance, scholars and journalists who did not clearly support the 'war on terror' in the wake of $9 / 11$ were exposed to various forms of discipline. ${ }^{81}$ Hence, Bially Mattern fails to acknowledge that practices commonly labelled and understood as soft power - again, what we call representational force - are underpinned by an exercise of power that operates beyond the level of subjectivity, on the very bodies of the subjects of power.

While this article argues that narratives and discourses become socially dominant through disciplinary power, ${ }^{82}$ physical sanctions do not need to be activated to produce the desired disciplinary effects. Rigorous surveillance - that is, 'a system that exhaustively maps and monitors those that it disciplines ${ }^{83}$ - plus the latent threat of sanctions can suffice to bring audiences into the fold. It is worth noting, however, that the manifest and latent exercise of disciplinary power does not necessarily result in exhaustive control of the conduct of others, in part because there is 'no power without potential refusal or revolt'. ${ }^{84}$

Although discipline is not the same as Gulag, productive and disciplinary power may nonetheless intersect to make phenomena such as Gulag thinkable and politically possible. In other words, the exercise of productive and disciplinary power that is unleashed through and relied on by what we have now come to think of as representational force is never far removed from practices commonly understood as hard power - what we follow Bially Mattern in calling 'physical force. ${ }^{85}$ Foucault writes that productive and disciplinary forms of power merge 'to act upon the actions of others' ${ }^{86}$ While President Bush exercised representational force in part by drawing on a larger discourse on terrorism and rogue states, his statement was not only complicit in

\footnotetext{
dependent on prior socialisation of target audiences, but states that 'potential sources of soft power (whatever they are) become real sources of soft power only when a receiver voluntarily develops a policy interest in importing and emulating them' (emphasis added). This is not quite how we understand productive power.

${ }^{77}$ Foucault, Discipline and Punish, p. 199.

${ }^{78}$ Michel Foucault, 'Body/power', in Colin Gordon (ed.), Power/Knowledge: Selected Interviews \& Other Writings (New York: Pantheon, 1980), p. 55.

${ }^{79}$ Foucault, Discipline and Punish, p. 104.

${ }^{80}$ Bially Mattern, 'Why "soft power" isn't so soft', p. 606.

${ }^{81}$ For examples, see William Bruneau and James Turk (eds), Disciplining Dissent: The Curbing of Free Expression in Academia and the Media (Toronto: James Lorimer \& Company, 2004).

${ }^{82}$ Eva Herschinger, "Hell is the Other": Conceptualising hegemony and identity through discourse theory', Millennium: Journal of International Affairs, 41:1 (2012), p. 67.

${ }^{83}$ Steve Herbert, 'The geopolitics of the police: Foucault, disciplinary power and the tactics of the Los Angeles Police Department', Political Geography, 15:1 (1996), p. 49.

${ }^{84}$ Michel Foucault, 'The subject and power', in J. D. Faubion (ed.), Power (New York: The New Press, 2000), p. 324.

${ }^{85}$ Bially Mattern, 'Why "soft power" isn't so soft', p. 586.

${ }^{86}$ Foucault, 'The subject and power', p. 344.
} 
disciplining domestic dissenters, but also enabled the US deployment of physical force in Afghanistan and Iraq.

Thus understood, it seems difficult to uphold the notion that representational force is 'normatively more appealing' than physical force. ${ }^{87}$ While some previous studies correctly hint that 'there is no hard power without prior soft power', ${ }^{88}$ and that the 'aim of soft power is ... to establish symbolically the legitimacy of war, ${ }^{89}$ they have yet to consider how productive and disciplinary forms of power intervene in and blur the operation of representational and physical force, and the performative role that the soft/hard power binary plays therein.

\section{The Sino-Japanese territorial dispute}

China and Japan's testy relationship around the disputed Diaoyu/Senkaku Islands has most frequently been analysed as a case of resource competition, ${ }^{90}$ virulent popular nationalism, and/or bitter memory politics. ${ }^{91}$ Soft power, by contrast, is said to be 'almost entirely absent from the Beijing-Tokyo relationship today'. ${ }^{92}$ This, however, is to misread the nature of practices commonly labelled and understood as soft power. While the designation of threats and militarisation can be linked to resource competition and nationalism, they are also made politically possible and imperative precisely through the exercise of representational force, underpinned by productive power and physically enforced through disciplinary power.

This section begins by inquiring whether - and, if so, how - Beijing and Tokyo have used representational force in the context of the islands dispute, in attempts to get audiences around the world to empathise and identify with the Self and against the Other. It then assesses how the productive power of dominant discourse about what is good/bad in international politics underpins and enables their respective use of representational force. The third task is to analyse how the distinctions normalised through productive power have been physically enforced on audiences in China and Japan. In the last step, we explore how the use of representational force legitimises and enables the use of physical force, through the intervention of productive and disciplinary power. The analysis covers the intensification of the dispute since September 2010, when a Chinese fishing trawler and two Japanese coastguard vessels collided near the disputed islands.

\section{Representational force}

'Cultural soft power' was included as a key theme of China's international strategy in the early 2000s. ${ }^{93}$ This endeavour was strategic as well as performative in that China's soft power campaign was aimed not just at strengthening China's soft power (in terms of resources or strategies), but also at representing China as a soft power (in terms of identity). At a 2014 conference, President $\mathrm{Xi}$ Jinping stated, 'We should increase China's soft power, give a good Chinese narrative, and

\footnotetext{
${ }^{87}$ Bially Mattern, 'Why “soft power” isn't so soft', p. 612.

${ }^{88}$ Dejan Verčič, 'Public relations and power: How hard is soft power?', in Ansgar Zerfass, Betteke van Ruler, and Krishnamurthy Sriramesh (eds), Public Relations Research: European and International Perspectives and Innovations (Berlin: Springer, 2008), p. 276.

${ }^{89}$ Lilie Chouliaraki, 'Introduction: the soft power of war: Legitimacy and community in Iraq War discourse', in Lilie Chouliaraki (ed.), The Soft Power of War (Amsterdam and Philadelphia: John Benjamins Publishing Company, 2005), p. 2, emphasis in the original.

${ }^{90}$ James C. Hsiung, 'Sea power, the Law of the Sea, and the Sino-Japanese East China Sea "resource war", American Foreign Policy Interest, 27:6 (2005), pp. 513-29.

${ }^{91}$ Karl Gustafsson, 'Is China's discursive power increasing? The "power of the past" in Sino-Japanese relations', Asian Perspective, 38:3 (2014), pp. 411-33; Peter Hays Gries, Derek Steiger, and Teo Wang, 'Popular nationalism and China's Japan policy: the Diaoyu Islands protests, 2012-2013', Journal of Contemporary China, 25:98 (2016), pp. $264-76$.

${ }^{92}$ Panda, 'Soft power and China-Japan relations'.

${ }^{93}$ Callahan, 'Identity and security in China', p. 218.
} 
better communicate China's message to the world. ${ }^{, 94}$ This shows that the Chinese leadership understands soft power exactly in terms of getting international audiences to empathise and identity with Chinese narratives. This is also what Chinese policymakers try to do in the context of the islands dispute with Japan. In fact, they typically describe China as the softer party - calling China 'peaceful'95 and emphasising that Beijing would prefer a negotiated settlement. ${ }^{96}$ Although the quote from $\mathrm{Xi}$ above does not explicate that Beijing wishes to get international audiences to identify against China's Others, Chinese narratives on the disputed islands do differentiate Japan as the epitome of hard power. The latter is represented as so 'militaristic' that 'history may repeat itself.$^{97}$ On the eve of Japan's nationalisation of the disputed islands in September 2012, for instance, the Chinese Foreign Ministry denounced Japan's move as 'an outright denial of the outcomes of the victory of the World Anti-Fascist War and ... a grave challenge to the post-war international order. ${ }^{98}$

Chinese leaders thus paint a stark contrast between the peaceful Chinese Self and the belligerent Japanese Other. They deploy what we have come to understand as representational force to get other victims of Japanese aggression and victors in the Second World War to empathise and identify with China on these terms, ${ }^{99}$ implying that the target audience's ontological security may otherwise be at risk. For instance, China's ambassador to the United Kingdom stressed that the two countries are similar in that both were 'victims of fascism', with troops that 'fought side by side ${ }^{100}$ and eventually ended up on the winning side. ${ }^{101}$ China's allies from the Second World War should share its duty 'to oppose and condemn any words or actions aimed at invalidating ... the post-war international order' - notably Japan's revisionist behaviour related to the islands. ${ }^{102}$ Beijing has also done its best to sway German audiences by praising Germany, which, unlike Japan, has 'seriously reflected' on its dark history. ${ }^{103}$

The Japanese government has similarly sought 'to strengthen its soft power' in recent years by 'highlighting Japan's attractiveness' to a wide range of international audiences, ${ }^{104}$ from the US, South Korea, and the Association of Southeast Asian Nations (ASEAN) countries to Australia

\footnotetext{
${ }^{94}$ 'Xi eyes more enabling int'l environment for China's peaceful development', Xinhua (30 November 2014), available at: \{http://english.cri.cn/12394/2014/11/30/189s854461_1.htm\}.

${ }^{95}$ Liu Xiaoming, 'China responds to Japan's provocation', Financial Times (1 November 2012), available at: \{http://www.ft. $\mathrm{com} / \mathrm{intl} / \mathrm{cms} / \mathrm{s} / 0 / 83440 \mathrm{fd} 8-22 \mathrm{c2}-11 \mathrm{e} 2-938 \mathrm{~d}-00144$ feabdc0.html\#axzz3GgBI0WZg\}; Ministry of Foreign Affairs of the PRC, 'Li Keqiang Meets with Papua New Guinea Prime Minster O’Neill' (11 September 2012), available at: \{http://www.fmprc. gov.cn/mfa_eng/topics_665678/diaodao_665718/t969873.shtml\}; Liu Xiaoming, 'China and Britain won the war together', Daily Telegraph (1 January 2014), available at: \{http://www.telegraph.co.uk/comment/10546442/Liu-Xiaoming-China-andBritain-won-the-war-together.html\}; Xi Jinping, 'Speech Delivered by the President of the People's Republic of China, Xi Jinping, to the Koerber Foundation' (28 March 2014), available at: \{http://www.koerber-stiftung.de/en/international-affairs/ focus-new-east/xi-jinping-2014/speech-xi-jinping.html\}.

${ }^{96} \mathrm{Liu}$, 'China responds to Japan's provocation'.

${ }^{97}$ Gao Yanping 'The Holocaust shall never repeat itself, Jerusalem Post (20 January 2014), available at: \{http://www.jpost. com/Opinion/Op-Ed-Contributors/The-Holocaust-shall-never-repeat-itself-338801\}.

${ }^{98}$ Ministry of Foreign Affairs of the PRC, 'Statement of the Ministry of Foreign Affairs of the People's Republic of China' (10 September 2012), available at: $\{$ http://www.fmprc.gov.cn/mfa_eng/topics_665678/diaodao_665718/t968188.shtml\}.

${ }^{99}$ Cui Tiankai, 'Shinzo Abe risks ties with China in tribute to war criminals', Washington Post (9 January 2014), available at: \{http://www.washingtonpost.com/pb/opinions/shinzo-abe-risks-ties-with-china-in-tribute-to-war-criminals/2014/01/09/ dbd86e52-7887-11e3-af7f-13bf0e9965f6_story.html\}; Gao, 'The Holocaust shall never repeat itself; Liu, 'China responds to Japan's provocation'; Xi, 'Speech Delivered by the President of the People's Republic of China'.

${ }^{100}$ Liu, 'China responds to Japan's provocation'.

${ }^{101} \mathrm{Liu}$, 'China and Britain won the war together'.

${ }^{102} \mathrm{Liu}$, 'China and Britain won the war together'; see also Liu, 'China responds to Japan's provocation'; Ministry of Foreign Affairs of the PRC, 'Vice Foreign Minister Zhang Zhijun Gave Briefing to Chinese and Foreign Journalists on the Diaoyu Dao Issue (Transcript)' (27 October 2012), available at: \{http://www.fmprc.gov.cn/mfa_eng/topics_665678/diaodao_665718/ t983015.shtml\}.

${ }^{103} \mathrm{Liu}$, 'China responds to Japan's provocation'; Ministry of Foreign Affairs of the PRC, 'Li Keqiang Meets with Papua New Guinea Prime Minster O’Neill’.

${ }^{104}$ Government of Japan, National Security Strategy of Japan (Tokyo: Government of Japan, 2013), p. 23.
} 
and India as well as various European states. Plentiful references to Japan as 'peace-loving' and to Japan's values as 'universal' demonstrate that this is the Self that the government in Tokyo is trying to get others to empathise and identify with. ${ }^{105}$ There is an Other in Japanese narratives too, from which the Japanese Self is differentiated - namely an 'increasingly severe security environment', caused by 'an increasing number of cases of unilateral actions in an attempt to change the status quo by coercion without paying respect to existing international law'. ${ }^{106}$ China then quickly emerges as the state that is taking such actions 'in maritime and aerial domains, including the East China Sea and the South China Sea'. ${ }^{107}$

Japanese policymakers use similar Self/Other distinctions when they refer more specifically to the Senkaku/Diaoyu Islands. They represent China as a state seeking to 'change the status quo by force or coercion' ${ }^{108}$ and juxtapose aggressive China's revisionism with peaceful Japan's allegiance to the postwar international order. ${ }^{109}$ Indeed, Japan's sovereignty over the islands is based on the understanding that the 1951 San Francisco Peace Treaty placed them under US administration as part of the Nansei Shoto archipelago. ${ }^{110}$

In Sino-Japanese representational battles, the Japanese government moreover claims that it is merely voicing "logical" counterarguments' in response to the Chinese 'media blitz, ${ }^{111}$ 'propaganda', ${ }^{112}$ and 'Goebbelsian PR binge', after Nazi Germany's minister of propaganda in 1933-45. ${ }^{113}$ China is thus cast as the 'out-group that violates not only global democratic values and norms, but also the freedoms and rights of its own citizens. ${ }^{114}$ The criticism against China is not unfounded, of course, but this does not necessarily mean that Japan is all 'good' either. Yet, narratives on both sides compel audiences to empathise and identify with and against the binaries that structure them. For instance, according to Japan's largest newspaper, Yomiuri Shimbun, 'This kind of harassment [by China] is almost unthinkable in Japan and other free countries.'115

\section{Productive power}

Chinese and Japanese uses of representational force are curiously similar. Both seek to persuade audiences around the world to empathise and identify with the peace-loving, law/order-abiding Self and against the aggressive, law/order-violating Other, lest their ontological security be at risk. The discursively produced ideal is clearly to be a peaceful status quo power and a soft power,

\footnotetext{
${ }^{105}$ Ibid., pp. 17-18; Prime Minister's Office, 'Cabinet Decision on Development of Seamless Security Legislation to Ensure Japan's Survival and Protect its People’ (1 July 2014), available at: \{https://japan.kantei.go.jp/96_abe/decisions/index.html\}.

${ }^{106}$ Government of Japan, National Security Strategy of Japan, pp. 17, 20.

${ }^{107}$ Ibid., p. 22; see also Ministry of Defense of Japan, National Defense Program Guidelines for FY 2014 and Beyond (17 December 2013), pp. 3-5, available at: \{http://www.mod.go.jp/j/approach/agenda/guideline/2014/pdf/20131217_e2.pdf\}.

${ }^{108}$ Ministry of Foreign Affairs of Japan, 'Ambassador to Italy Masaharu Kohno's Article to Il Messaggero' (6 February 2014), available at: \{http://www.mofa.go.jp/p_pd/ip/page24e_000032.html\}.

${ }^{109}$ Koichiro Gemba, 'Japan-China relations at a crossroads', New York Times (20 November 2012), available at: \{http:// www.nytimes.com/2012/11/21/opinion/koichiro-genba-japan-china-relations-at-a-crossroads.html\}; Keiichi Hayashi, 'It is time for China to calm down', Financial Times (13 November 2012), available at: \{http://www.ft.com/cms/s/0/9c2802622cf8-11e2-9211-00144feabdc0.html\}; Ministry of Foreign Affairs of Japan, 'Ambassador to Italy Masaharu Kohno's Article to Il Messaggero'; Kenichiro Sasae, 'China’s propaganda campaign against Japan', Washington Post (26 January 2014), available at: $\{$ http://www.washingtonpost.com/opinions/chinas-propaganda-campaign-against-japan/2014/01/16/925ed924-7caa11e3-93c1-0e888170b723_story.html\}.

${ }^{110}$ Hayashi, 'It is time for China to calm down'.

${ }^{111}$ 'Senkakus: Tense waters/quantity vs. logic in "propaganda war"', Japan News (7 October 2013), available at: \{http://article.wn.com/view/2013/10/06/SENKAKUS_tense_waters_Quantity_vs_logic_in_propaganda_war\}.

${ }^{112}$ See, for example, Sasae, 'China's propaganda campaign against Japan'; 'Senkakus', Japan News.

${ }^{113}$ Tomohiko Taniguchi, quoted in Linda Sieg and Ben Blanchard, 'Japan on backfoot in global PR war with China after Abe shrine visit', Reuters (12 February 2014), available at: \{http://www.reuters.com/article/2014/02/12/us-japan-china-pridUSBREA1B24520140212\}.

${ }^{114}$ Michael Chan, 'The discursive reproduction of ideologies and national identities in the Chinese and Japanese English-language press', Discourse and Communication, 6:4 (2012), p. 372.

${ }^{115}$ Quoted in ibid.
} 
while the revisionist use of hard power is deemed illegitimately different. Thus, instead of merely drawing on attractive resources 'out there', China and Japan's respective use of representational force is enabled and constrained through the operation of productive power. Productive power produces the Self/Other representations that China and Japan rely on and affects the receptivity of audiences to empathising and identifying with them.

This dominant discursive structure is not politically neutral or value-free, however, as China is more often found wanting in discussions on status quo/revisionism than Japan. ${ }^{116}$ China's narrative of itself as a peaceful status quo power and Japan as a belligerent revisionist power faces more of an uphill battle than the Japanese narrative. Hence, it is not surprising that some Western observers have begun to label China's very attempt to gain soft power as sharp power, if not outright hard power. ${ }^{117}$ Chinese attempts to get German Chancellor Angela Merkel to empathise and identify with the Chinese Self and against the Japanese Other, for instance, were ultimately to no avail. ${ }^{118}$

US, European, Australian, Indian, and Southeast Asian policymakers have not voiced unequivocal support for the Japanese narrative on the disputed islands either, which is essentially that no dispute exists, yet they regularly voice their agreement with the Japanese government's preferred Self/Other representations. ${ }^{119}$ European Council President Donald Tusk, for example, recently stated that Japan and the European Union share common values and challenges:

We remain united by our common values of liberal democracy and the rule of law as the core principles of the rules-based international order. ... We share a common interest in preserving G7 unity in strengthening the rules-based international order to address common challenges - from the economy and trade to climate change, migration, security and terrorism; from the East and South China Seas, North Korea, to the conflicts in Syria and the wider Middle East, to Ukraine. ${ }^{120}$

By this point, it should be clear that audiences are more easily compelled to accept an actor's narrative if it resonates with the dominant discourse. In projecting their desired identities, China and Japan are within this discursive structure. Hence, the greater effectiveness of Japan's use of representational force has less to do with Japan's internal resources or inherent softness, than with the hegemonic and even quietly coercive nature of the prevailing discourse.

\section{Disciplinary power}

Underpinned and enabled by productive power, the Self/Other representations reflected in China and Japan's respective uses of representational force are further enforced through the operation of disciplinary power. In China, it is common for people who stray from the dominant

\footnotetext{
${ }^{116}$ David Shambaugh, 'China or America: Which is the revisionist power?', Survival, 43:3 (2001), pp. 25-30; Walter Russell Mead, 'The return of geopolitics: the revenge of the revisionist powers', Foreign Affairs, 93:3 (2014), pp. 69-79.

${ }^{117}$ Walker and Ludwig, 'The meaning of sharp power'; Nye, 'How sharp power threatens soft power'.

${ }^{118}$ 'Berlin nixes holocaust memorial request', Spiegel Online (3 March 2014), available at: $\{$ http://www.spiegel.de/international/germany/no-holocaust-memorials-for-china-president-xi-on-trip-to-berlin-a-956574.html\}.

${ }^{119}$ Ministry of External Affairs of India, 'India-Japan Joint Statement during Visit of Prime Minister of Japan to India' (14 September 2017), available at: \{http://www.mea.gov.in/bilateral-documents.htm?dtl/28946/IndiaJapan+Joint+Statement+during+visit+of+Prime+Minister+of+Japan+to+India+September+14+2017\}; Minister for Foreign Affairs of Australia, 'Joint Statement: Seventh Japan-Australia 2+2 Foreign and Defence Ministerial Consultations' (20 April 2017), available at: \{https://foreignminister.gov.au/releases/Pages/2017/jb_mr_170420.aspx\}; Minister for Foreign Affairs of Japan, 'JapanASEAN Summit Meeting' (13 November 2017), available at: $\{$ http://www.mofa.go.jp/a_o/rp/page3e_000791.html\}; NATO, 'Joint Press Statement Issued on the Occasion of the Meeting between the NATO Secretary General, H. E. Mr Jens Stoltenberg and H. E. Mr Shinzo Abe, Prime Minister of Japan' (31 October 2017), available at: \{https://www.nato.int/cps/ en/natohq/opinions_148029.htm?selectedLocale=en\}.

${ }^{120}$ Donald Tusk, 'Remarks by President Donald Tusk before the EU-Japan Leaders' Meeting', European Council (21 March 2017), available at: \{http://www.consilium.europa.eu/sv/press/press-releases/2017/03/21/tusk-joint-meeting-abe/? +by+President+Donald+Tusk+before+the+EU-Japan+Leaders $\% 27+$ meeting\} .
} 
Self/Other narrative related to the disputed islands to be called 'traitors' (hanjian). Taiwan's former president, Lee Teng-hui, for instance, was widely labelled a traitor for suggesting that the islands belong to Japan rather than China. ${ }^{121}$ Moreover, after condemning the 'pointlessness' of the territorial dispute, the liberal economist Mao Yushi was called a 'Japanese and American dog' who deserved to be killed in a post on the popular Chinese Internet forum Tianya. ${ }^{122}$ Even Chinese tourists visiting Japan were not immune from censure during the time when the islands dispute raged most intensely. ${ }^{123}$ A post from 'Bizarre Zi' on the popular Chinese website douban.com told how when 'father found out I was organising my tourist visa to Japan, he lashed out at me almost to the point of making me cry'. Bizarre Zi put his/ her dilemma to other users, asking whether s/he should give up the trip. ${ }^{124}$

Moreover, around the time of Japan's nationalisation of the islands in 2012, in parts of China it was not safe to display any connection with Japan. In Qingdao, protesters broke into a dozen Japanese-run factories and set a Panasonic plant on fire. ${ }^{125}$ Japanese cars and restaurants in China were also targeted. ${ }^{126}$ The victims, in most cases Chinese business or car owners, were sent the message that even the slightest and most ambiguous association with the Japanese Other would not be tolerated. Or, to use a line from another Tianya post, "To drive a Japanese car is to dig your own grave. ${ }^{127}$ For Li Jianli, the owner of a Japanese car, this was not an empty threat - a young man smashed his skull during anti-Japanese riots in Xi'an. The young man's mother said the source of her son's 'patriotic' rage was Chinese television: 'When we turn on the TV, most of the dramas are about the anti-Japanese war. How would it be possible not to hate the Japanese?'. ${ }^{28} \mathrm{Li}$ Jianli was still 'unable to function independently' four years later. Nonetheless, his wife was not angry with the protesters: 'Perhaps Japan is all to blame for this, for stealing our Diaoyu islands. If they wouldn't have done that, there would have been no protests. ${ }^{\prime 29}$ That the victim's wife refused to blame the perpetrator but instead turned her anger on China's Other, Japan, demonstrates how profoundly she had been disciplined.

Japanese who challenge or problematise the official version of the historical and legal background to the islands dispute, or advocate a more moderate and conciliatory Japanese policy, are also branded traitors. For instance, when former Prime Minister Hatoyama Yukio acknowledged the existence of a territorial dispute during a visit to China in January 2013, then Defence Minister Onodera Itsunori immediately denounced him as a traitor (kokuzoku). ${ }^{130}$ Former Governor of Tokyo Ishihara Shintarō also called a candidate in Tokyo's gubernatorial election in 2016, Torigoe Shuntarō, a traitor (baikokudo) for saying that the disputed islands were not

\footnotetext{
${ }^{121} \mathrm{Su}$ Yun, 'Li Denghui biaoyan “mori diankuang” [The “doomsday hysteria” performance of Lee Tenghui]', Renmin ribao haiwaiban [People's Daily, overseas edn] (29 July 2015), p. 3.

${ }^{122}$ 'Dui Mao Yushi zheyang de Riben he Meiguo Gou bixu shadiao! [Such Japanese and American dogs as Mao Yushi must be killed!]', Tianya (5 May 2013), available at: \{http://bbs.tianya.cn/post-free-3275018-1.shtml\}.

${ }^{123}$ Amrutha Gayathri, 'Chinese tourists warmly received in Japan, criticized in China', International Business Times (24 October 2012), available at: \{http://www.ibtimes.com/chinese-tourists-warmly-received-japan-criticized-china-852788\}.

${ }^{124}$ 'Woba shuo qu Riben lüyou jiushi Hanjian, maiguo, qu haishi buqu? [My father maintains that a visitor to Japan is simply a traitor who betrays China: Should I go or not?]', douban.com (2013), available at: \{https://www.douban.com/ group/topic/40840150/\}.

${ }^{125}$ Zhao Suisheng, 'China's difficult relations with Japan: Pragmatism, superficial friendship, and historical memories', Asian Journal of Comparative Politics, 1:4 (2016), pp. 335-53 (p. 345).

${ }^{126}$ Kazunori Takada and Chris Buckley, 'Japan shuts factories, stores in China as islands dispute turns violent', Financial Post (17 September 2012), available at: \{http://business.financialpost.com/news/japan-shuts-factories-stores-in-china-asislands-dispute-turns-violent\}.

${ }^{127}$ Quoted in Gries, Steiger, and Wang, 'Popular nationalism and China's Japan policy', p. 270.

${ }^{128}$ Quoted in Zhao, 'China's difficult relations with Japan', p. 339.

${ }^{129}$ Manya Koetse, “I wish we never bought a Japanese car”: Lasting scars of anti-Japanese demonstrations', What's on Weibo (18 December 2016), available at: \{http://www.whatsonweibo.com/wish-never-bought-japanese-car-lasting-scarsanti-japanese-demonstrations/\}.

${ }^{130}$ 'Hatoyama wa "kokuzoku" to bōeishō [The Defense Minister: Hatoyama [is] a "traitor"]', Sankei Nyūsu (17 January 2013), available at: \{http://www.sankei.com/politics/news/130117/plt1301170004-n1.html\}.
} 
worth protecting. ${ }^{131}$ Moreover, since recognising in articles and commentary that China's territorial claim is not totally baseless, the retired diplomat Magosaki Ukeru has been blasted in thousands of tweets calling him a traitor, a liar, a loser, fake-Japanese, China's spy/dog/servant/agent, a slave, a leftist, and an idiot. He has also received direct death threats. ${ }^{132}$

Another form of disciplinary power operating in Japan is what Emeritus Professor Yabuki Susumu calls 'smothering' (mokusatsu). He writes that his dissenting historical analysis on the islands is treated in Japan 'as if it did not exist'. ${ }^{133}$ Another historian who challenges the historical evidence for Japan's ownership of the Senkaku Islands, Murata Tadayoshi, cannot get his articles published in Japanese. ${ }^{134}$ Magosaki also testifies that the national broadcaster, the NHK, as well as commercial channels have stopped asking him to appear. ${ }^{135}$ This allegedly happened after a Liberal Democratic Party (LDP) parliamentarian, Ōnishi Hideo, publicly questioned Magosaki's qualifications for commenting on the Senkaku Islands and other political issues. ${ }^{136}$ Yabuki further conjectures that scholars and journalists 'choose' not to diverge from the government line because of 'self-restriction' (jiko kisei) and 'self-censorship' (jiko ken'etsu). ${ }^{137}$

There are also more tangible forms of discipline in Japan, such as receiving 'nasty phone calls' or being harassed by members of ultra right-wing groups, as Suganuma Unryū, another Japanese historian, experienced. ${ }^{138}$ Japan's ambassador to China, Niwa Uichirō, became a target in 2012 after he warned that it could provoke an 'extremely grave crisis' between China and Japan if the Tokyo Metropolitan Government under then Governor Ishihara Shintarō went ahead with the planned purchase of the islands. ${ }^{139}$ Ishihara responded by calling Niwa unqualified, claiming that he 'needs to learn more about the history of his own country'. ${ }^{140}$ Several LDP Diet members also condemned the Noda administration for allowing Ambassador Niwa to make critical remarks about Ishihara. The Japanese government later rebuked Niwa, forcing him to apologise, and within six weeks had replaced him as ambassador.

One product of these disciplinary measures is a public sphere in which few dissenting views on the territorial dispute are being voiced. ${ }^{141}$ All Japanese political parties, for instance, have adopted the stance that the islands belong to Japan. Smith's choice of words is quite telling when she notes that, 'the call to rally around Japan's sovereign claims over the islands attracted a wide variety of Japanese citizens in the effort to demand a more assertive defense of the islands'. ${ }^{142}$ This

\footnotetext{
${ }^{131}$ 'Torigoe Shuntarō shi wa "baikokudoda, koitsu wa" Koike Yuriko shi wa "usotsuki" [Mr Torigoe Shuntarō is a "traitor", Ms Koike Yuriko is a "liar"]', Sankei Nyūsu (27 July 2016), available at: \{http://www.sankei.com/politics/news/160726/ plt1607260038-n1.html\}.

${ }^{132}$ Twitter search using the terms 'Senkaku' and 'Magosaki', and the time span 1 April to 31 December 2012; 731 of the tweets criticised him along these lines, while 384 tweets made positive remarks about his analysis of the dispute.

${ }^{133}$ Email correspondence between Linus Hagström (co-author of this article) and Yabuki Susumu, 'Re: Domestic politics of the Senkaku issue in Japan', 13 October 2017.

${ }^{134}$ Email correspondence between Hagström and Murata Tadayoshi, 'Re: SV: Otioawase' (Re: SV: Request), 4 October 2017.

${ }^{135}$ Email correspondence between Hagström and Magosaki Ukeru, 'Re: Debating Senkaku in Japan', 18 September 2017.

${ }^{136}$ Onishi Hideo, 'Address to the General Affairs Committee, House of Representatives' (21 March 2013), available at: $\{$ http://kokkai.ndl.go.jp/\}.

${ }^{137}$ Email correspondence: Yabuki, 'Re: Domestic politics of the Senkaku issue in Japan'.

${ }^{138}$ Email correspondence between Hagström and Suganuma Unryū, 'Response', 13 September 2017; cf. Email correspondences: Murata, 'Re: SV: Otioawase'; Yabuki, 'Re: Domestic politics of the Senkaku issue in Japan'.

${ }^{139}$ Mure Dickie, 'Tokyo warned over plans to buy islands', Financial Times (6 June 2012), available at: \{https://www.ft.com/ content/af98fc54-aef7-11e1-a4e0-00144feabdc0\}.

${ }^{140 ، G e m b a}$ rebukes Japan's envoy to China over Senkaku remarks', Japan Today (12 June 2012), available at: \{https://www. japantoday.com/smartphone/view/politics/gemba-rebukes-tokyos-ambassador-to-china-over-senkaku-remarks\}.

${ }^{141}$ Takeshi Suzuki and Shusuke Murai, 'How the Japanese legacy media covered the Senkaku controversy', in Thomas A. Hollihan (ed.), The Dispute over the Diaoyu/Senkaku Islands: How Media Narratives Shape Public Opinion and Challenge the Global Order (New York: Palgrave Macmillan, 2014), p. 143.

${ }^{142}$ Sheila Smith, Intimate Rivals: Japanese Domestic Politics and a Rising China (New York: Columbia University Press, 2016), p. 219, emphasis added.
} 
attraction is enforced not just through representational force but, as is demonstrated above, also through the threat and use of physical sanctions by which any dissent is quenched.

\section{Physical force}

Similar, albeit not necessarily identical, forms of intimidation and violence have thus been used in China and Japan to discipline citizens into accepting the dominant Self/Other representations that are central to each state's use of representational force with regard to the islands dispute. This violence, moreover, is closely connected with violence and preparations for violence directed against the Other. To begin with, during the demonstrations in China rocks and debris were thrown at Japanese diplomatic missions and Japanese citizens were injured. ${ }^{143}$ In the case of Japan, live bullets were sent to the Chinese Embassy in Tokyo in 2012, and burning objects were thrown at China's diplomatic and consular missions in the country. ${ }^{144}$

The governments in Beijing and Tokyo may not have encouraged street-level violence, but mutually antagonistic processes of identification have undoubtedly set the stage for such violence and they have begun to normalise military preparations in both states. Shusuke Murai and Takeshi Suzuki, for example, show that traitor narratives exist side-by-side with calls for a military attack on China in Japanese nationalist Internet discourse. ${ }^{145}$ Indeed, the binaries reproduced as part of both governments' uses of representative force are not just underpinned by productive power and enforced domestically through the operation of disciplinary power - they also help to legitimise and enable arms build-ups on both sides by making them seem reasonable, and even imperative.

This logic is evident in China's hardening policy vis-à-vis Japan: 'Every time Japan and the Diaoyu/Senkaku dispute comes up in the news, people in China become emotional and angry. Chinese leaders and officials cannot afford to be seen as soft towards Japan.' ${ }^{146}$ Retired Major General Luo Yuan has called on the government to use the Diaoyu Islands as a target range, while a professor from China's National Defense University has urged China to seize Japanese vessels around the islands: 'If the Japanese Self-Defense Forces dare to intervene, our warships should be called in. ${ }^{, 147}$ Following Japan's nationalisation of the disputed islands, China started regular patrols by ocean surveillance ships in the disputed waters. At the end of 2013, Beijing declared an Air Defence Identification Zone (ADIZ) that includes the Diaoyu Islands. In February 2017, shortly after then US Defense Secretary James Mattis confirmed that the USJapan mutual defence treaty applies to the Senkaku/Diaoyu Islands, China conducted a new round of regular patrols in the islands' territorial waters. In 2012, Japan and China had 51 and 40 coastguard vessels, respectively. By 2019, the Japanese government estimates that China will have 135 vessels, more than double Japan's $65 .^{148}$

In the case of Japan, policymakers have justified security and defence policy changes in recent years largely by invoking China's assertiveness and agglomeration of hard power, particularly

\footnotetext{
${ }^{143}$ Ministry of Foreign Affairs of Japan, 'Senkaku Islands Q\&A' (13 April 2016), available at: \{http://www.mofa.go.jp/ region/asia-paci/senkaku/qa_1010.html\}.

${ }^{144}$ Ministry of Foreign Affairs of the PRC, 'Statement of the Ministry of Foreign Affairs of the People's Republic of China'.

${ }^{145}$ Shusuke Murai and Takeshi Suzuki, 'How the Japanese social media users discussed the Senkaku controversy', in Hollihan (ed.), The Dispute over the Diaoyu/Senkaku Islands, pp. 169-99.

${ }^{146}$ Ren Xiao, 'Diaoyu/Senkaku disputes: a view from China', East Asia Forum (4 November 2013), available at: \{http:// www.eastasiaforum.org/2013/11/04/diaoyusenkaku-disputes-a-view-from-china/\}.

${ }^{147}$ 'Luo Yuan: Ying ba Diaoyudao huawei bachang daxiang "haishang renmin zhanzheng" [Luo Yuan: Diaoyu Islands should become target range to launch a "maritime people's war"]', Huanqiuwang (21 August 2012), available at: \{http:// world.huanqiu.com/exclusive/2012-08/3048388.html\}.

${ }^{148}$ Alexander Neil, 'Japan's growing concern over China's naval might', BBC News (28 May 2017), available at: \{http://www. bbc.com/news/world-asia-39918647\}.
} 
around the disputed islands. ${ }^{149}$ Between 2012 and 2016, Japan's defence expenditure grew by 4.5 per cent, and it increased its fleets of destroyers, submarines, fighters, and combat aircraft. Moreover, the legal and institutional framework for the use of force has developed quite radically following the quadruple launch in December 2013 of a National Security Council, a National Security Strategy, revised National Defense Programme Guidelines, and a Medium-Term Defense Programme. The framework also involves the July 2014 'Cabinet Decision on Development of Seamless Security Legislation to Ensure Japan's Survival and Protect its People', and a legal framework, adopted a year later, for ensuring Japan's capacity to exercise collective self-defence. In 2015, Tokyo and Washington upgraded their security ties for the first time since 1997, and Japan has formalised security cooperation with Australia and India, and advanced closer security ties with several ASEAN countries. It has not only taken part in several joint military exercises and consultations with all these countries, but also helped Southeast Asian states to 'improve maritime safety' and 'respond to China's growing assertiveness at sea'. ${ }^{150}$ Amid the growing presence of Chinese military aircraft in the islands' air space, in 2016 Japanese fighter planes scrambled nearly twice a day to warn off incoming aircraft, compared to less than twice a month in 2008. ${ }^{151}$ The Japanese coastguard has also enhanced its presence around the islands. Meanwhile, the weight of Japan's military has shifted from Hokkaido to the Nansei Islands where the disputed islands are located. Nearly 10,000 Japanese troops will be stationed on islands in the East China Sea, 'along with a network of antiship and antiaircraft missiles.' ${ }^{152}$

Both states have thus boosted their military presence around the disputed islands, and the number of near misses has increased, involving ships as well as aircraft. For example, Chinese and Japanese fighters shadowed each other near the islands in December 2012 and a Chinese frigate locked its missile radar on to a Japanese ship in early 2013. Some analysts have expressed concern that this could lead to a war between China and Japan. ${ }^{153}$ It is worth noting that such a high-stakes power play, which is legitimised and enabled through the use of representational force and underpinned by productive and disciplinary forms of power, can also be construed as enhancing the actors' attractiveness. For example, on 18 September 2012, a People's Daily editorial opined that China's various moves and countermeasures 'indicate the mature rationality of a great power ... and have won the respect and recognition of international society. ${ }^{154}$ Similarly, in Japan, Prime Minister Abe Shinzō has drawn a link between his ambition to enhance military interoperability and cooperation among Japan, the US, India, and Australia and his vision for building Japan into 'a beautiful country', through which he hopes to attract domestic and international audiences. ${ }^{155}$

\section{Conclusions and implications}

The dominant view in the IR literature is that soft power and hard power are empirically and normatively dichotomous and practically opposite. We argue that this soft/hard power binary

\footnotetext{
${ }^{149}$ Linus Hagström, "Power shift" in East Asia? A critical reappraisal of narratives on the Diaoyu/Senkaku Islands incident in 2010', Chinese Journal of International Politics, 5:3 (2012), pp. 267-97; Sebastian Maslow, 'A blueprint for a strong Japan? Abe Shinzō and Japan's evolving security system', Asian Survey, 55:4 (2015), pp. 739-65.

${ }^{150}$ ‘Japan Coast Guard to set up liaison body to help Southeast Asian counterparts deal with China', Japan Times (7 January 2017), available at: \{http://www.japantimes.co.jp/news/2017/01/07/national/politics-diplomacy/japan-set-bodybolster-southeast-asian-coast-guards-amid-chinese-assertiveness-sea/\}.

${ }^{151}$ Emma Graham-Harrison, 'Islands on the frontline of a new global flashpoint: China v Japan', The Guardian (5 February 2017), available at: \{https://www.theguardian.com/world/2017/feb/05/china-v-japan-new-global-flashpointsenkaku-islands-ishigaki\}.

${ }^{152}$ Michael Auslin, 'Japan's new realism: Abe gets tough', Foreign Affairs, 95:2 (2016), p. 131.

${ }^{153}$ See, for example, James Holmes, 'Asia's worst nightmare: a China-Japan war', The National Interest (26 October 2014), available at: $\{$ http://nationalinterest.org/commentary/asias-ultimate-nightmare-china-japan-war-9662\}.

${ }^{154}$ Quoted in Gries, Steiger, and Wang, 'Popular nationalism and China's Japan policy', p. 272.

${ }^{155}$ Yuki Tatsumi, 'Is Japan ready for the quad? Opportunities and challenges for Tokyo in a changing Indo-Pacific', War on the Rocks (9 January 2018), available at: \{https://warontherocks.com/2018/01/japan-ready-quad-opportunities-challengestokyo-changing-indo-pacific/\}.
} 
epitomises the power politics of power analysis in IR and inhibits our ability to understand complex power dynamics in international politics. The binary view is arguably attractive because it helps order the world in terms of soft versus hard, where the former is typically associated with the Self and the latter connected with the Other. In this article, we began by problematising these seemingly natural categories, demonstrating how they are discursively co-constituted. We then revealed how practices commonly labelled and understood as soft power (that is, representational force) legitimise and enable practices labelled and understood as hard power (that is, physical force) in a process that we conceptualise as being underpinned by the operation of productive power and disciplinary power. Both critiques traverse the binary view of soft and hard power, thus problematising the very basis for Self/Other distinctions on which power continues to be conceptualised and practiced.

We illustrate the analytical generality of the second critique by analysing the Sino-Japanese dispute over the Senkaku/Diaoyu Islands. The dispute reflects the struggles of and for both representational and physical force and the way the two intertwine in practice. Importantly, the use of representational force on both sides involves verbal coercion and is underpinned by the productive power of discourse. It also provides the permissive context for the use of disciplinary power against those lumped together with the Other and enables the use of physical force against the Other in defence of the Self. The first critique is clearly of relevance here as soft power and hard power are among the identity signifiers that are used to distinguish Self from Other.

Given the potentially dangerous implications of these power dynamics, resorting to more 'soft power diplomacy' may not be as conducive to defusing tensions as is commonly assumed. As conceptualised and practiced, soft power is both predicated on and constitutive of the very Self/Other dichotomy that has plagued Sino-Japanese relations and increased the danger of violent conflict. This article at least helps complicate matters by showing that representational force legitimises and enables physical force in ways that are similar in China and Japan, in both cases underpinned by the productive power of discourse and enforced on domestic audiences through the operation of disciplinary power. While Chinese and Japanese government officials and scholars are intent on emphasising how different the two countries are, this article has gone some way towards blurring the distinction.

Acknowledgements. This article was presented at the ISA Convention in Baltimore, MD, in February 2017. For their helpful comments on previous drafts, we would like to thank Ruth Blakeley and three anonymous reviewers of Review of International Studies, Henrik Chetan Aspengren, Felix Berenskötter, Sara Bondesson, Alex Bukh, Kjell Engelbrekt, Lindy Newlove-Eriksson, Karl Gustafsson, Maria Hellman, Arita Holmberg, Björn Jerdén, Tom Lundborg, Nicola Nymalm, Nicholas Olczak, Eva-Karin Olsson, and (last but not least) Stephanie Winkler. We are very grateful to Magosaki Ukeru, Murata Tadayoshi, Sunganuma Unryū, and Yabuki Susumu, who kindly agreed to be interviewed via email. We also wish to thank Nakako Hattori and Aron Woonink for excellent research assistance. Finally, Linus Hagström acknowledges the research funding from the Marianne and Marcus Wallenberg Foundation (MMW 2013.0162), as well as the scholarship from the Harald and Louise Ekman's Foundation, which made it possible to spend a week writing at the Sigtuna Foundation.

Linus Hagström is Professor of Political Science at the Swedish Defence University and a Senior Research Fellow at the Swedish Institute of International Affairs. He has recently published articles in International Studies Review; Journal of Japanese Studies; Survival; European Political Science; Washington Quarterly; and European Journal of International Relations and has edited special issues for Cambridge Review of International Affairs; The Pacific Review; and Asian Perspective. Author's email: linus.hagstrom@fhs.se

Chengxin Pan is Associate Professor of International Relations at Deakin University, Victoria, Australia and a co-editor of the Global Political Sociology series (Palgrave Macmillan). He recently published in Politics; Journal of Contemporary China; International Relations of the Asia-Pacific; European Journal of International Relations; Contemporary Politics; and Australian Journal of International Affairs. Author's mail: chengxin.pan@deakin.edu.au

Cite this article: Hagström, L., Pan, C. 2020. Traversing the soft/hard power binary: the case of the Sino-Japanese territorial dispute. Review of International Studies 46, 37-55. https://doi.org/10.1017/S0260210519000251 